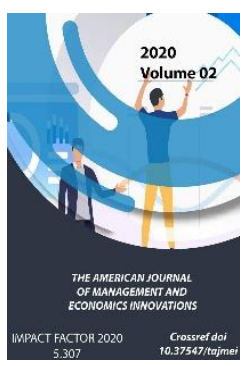

\title{
Assessment Of Cost Of Treating Malaria Fever Among Arable Yield Cultivating Family Units In Niger State
}

\author{
P. A. Ayinde \\ Department Of Agricultural Economics And Farm Management, University Of Agriculture, \\ Abeokuta, Nigeria
}

\section{ABSTRACT}

This examination assessed the monetary expense of malaria fever and decided creation and intestinal sickness related elements influencing ranch income. A multi-stage arbitrary testing technique was utilized to choose 100 and 28 arable yield cultivating families from whom information were gathered for the examination. Information gathered were examined utilizing graphic measurements, numbercrunching files, t-trial of distinction of two methods and Normal Least square relapse technique. The outcomes uncovered that a normal family unit had nine individuals. About $6.5 \%$ of examined families looked for medical services in the public authority clinics, while 30.5 and $20 \%$ of the tested family units disparaged patent prescriptions stores and customary carers separately. The amount of N7,415.41k was caused as monetary expense of intestinal sickness per family unit per annum in the examination zone. Ranch size, employed work, consolidated malaria fever treatment expenses and days lost to intestinal sickness assault were huge elements influencing Homestead Income. The examination prescribed need regard for rustic regions in malaria fever control program; improvement in medical care conveyance framework and consolidation of conventional clinical professionals in the medical services framework

\section{KEYWORDS}

Cost, Arable Harvests, Cultivating Families 


\section{INTRODUCTION}

This infection disables the expectations for everyday comforts of Africans and furthermore forestalls improvement of expectations for everyday comforts of people in the future. As like clockwork a kid passes on of malaria fever, bringing about a day by day loss of in excess of 2,000 youthful lives around the world. These appraisals render intestinal sickness the superior tropical parasitic infection and one of the main three executioners among transferable illnesses. World Monetary Gathering announced that the danger of malaria fever exists all through Nigeria. This compromises work accessibility and productivity of homestead activities. Demonstrated different manners by which ranch work supply is influenced by sickness disease. It was asserted that the 'immediate' impact of sickness results when a working individual from family unit is kept from chipping away at the homestead because of illness contamination.

Improved wellbeing adds to financial development fourly: it diminishes creation misfortunes brought about by laborer ailment; it allows the utilization of normal assets that had been absolutely or almost out of reach due to illness; it expands the enlistment of kids in schools and improves them ready to learn; and it makes elective employments of assets that would somehow or another must be spent on treatment. The most clear wellsprings of gain from better laborers are investment funds of workdays, expanded profitability, more prominent betterpaying open positions, and longer working lives.

\section{Philosophy}

Strategies for Information Assortment and Examining Procedure Information were gathered with the guide of all around organized surveys which were controlled to the chose family units. Information were gathered on the malaria fever ailment scenes, days lost to ailment, cost of disease, treatment techniques, adapting methodologies, ranch data sources, yields and costs. This examination embraced a multi-stage testing method. The main stage included choice of two out of the three Agrarian Advancement Ventures zones through purposive inspecting procedure dependent on the Niger state month to month Epidemiological reports.

\section{Model detail:}

$Q=f\left(X_{1}, X_{2}, X_{3}, X_{4}, X_{5}, X_{6},\right)-(1)$ where

$\mathrm{Q}=$ Homestead Income $(\mathrm{N})$

$\mathrm{X} 1$ = Land size (hectare)

$\mathrm{X}_{2}=$ Family work $(\mathrm{N})$

$\mathrm{X}_{3}=\operatorname{Recruited}$ work $(\mathrm{N})$

$\mathrm{X}_{4}=$ different costs (cost of manure, seeds, bug spray $(\mathrm{N})$

$\mathrm{X}_{5}=\mathrm{J}$ oined intestinal sickness therapy and time cost $(\mathrm{N})$

X6 = anticipation cost $(\mathrm{N})$

$\mathrm{X}_{7}=$ Days lost to malaria fever assault $\mathrm{e}=$ mistake term

\section{RESULTS AND CONVERSATION}

Monetary expense of malaria fever that intestinal sickness beset family brought about N217.50 for customary strategies for therapy, N342.00 for standard techniques for therapy and N82.26 as transportation cost to the therapy site per scene. Also, N817.15 was exhausted on preventive measures, while time cost of wiped out individual and carer totalled N2,657.37 per intestinal sickness scene. For the most part, the monetary expense for treatment was $\mathrm{N} 1,283.52$ establishing $17.31 \%$ of 
the absolute expense of malaria fever treatment. Time cost was $\mathrm{N} 5,314.74$ speaking to $71.67 \%$ every year per family unit. Monetary expense of intestinal sickness therapy exhausts the family unit pay and may have negative impact on the family financial plan for ranch inputs. This is on the grounds that the scant family unit assets may in the long run be redirected to medical services, accordingly diminishing buying limit which would at last prompt decreased farming efficiency.

\section{CONCLUSION AND PROPOSAL}

In light of the outcomes acquired, the monetary expense of intestinal sickness was assessed at N7, 415.41 per family every year and this was $22 \%$ of the normal gross edge of the overviewed ranchers. There was huge contrast in the gross edge per hectare at various degrees of malaria fever scenes. The examination set up that intestinal sickness hardship in families has negative impact on pay because of participation loss of important labor and decreased profitability.

\section{REFERENCES}

1. Amara, N 2001. "Specialized effectiveness and ranchers demeanor towards mechanical development. The instance of potato ranchers in Quebec" Canadian Diary of Horticultural Financial aspects, 47(1): $31-43$.

2. Brundtland, G.O.H. 2010.: "A commitment On the planet Wellbeing Association". Report Press delivered during the African Highest point on Move Back Intestinal sickness, Abuja, Nigeria, April 25, 2010.
3. Evaluation 2016. Public Populace Commission Evaluation Report. Central Legislature of Nigeria, Abuja.

4. Jimoh, A. 2015. The intestinal sickness trouble and horticultural yield in Nigeria. Agrosearch. A Diary of Horticulture and Improvement, 7(1 and 2): $37-43$.

5. Meir, G. 2011. Driving Issues in Monetary Turn of events. fifth Version, Oxford College Press. NGS (2011). Niger State Administration of Nigeria Year Book. 